\title{
Treatment with bisphenol $A$ and methoxychlor results in the growth of human breast cancer cells and alteration of the expression of cell cycle-related genes, cyclin D1 and $p 21$, via an estrogen receptor-dependent signaling pathway
}

\author{
HYE-RIM LEE, KYUNG-A HWANG, MIN-AH PARK, BO-RIM YI, \\ EUI-BAE JEUNG and KYUNG-CHUL CHOI
}

\begin{abstract}
Laboratory of Veterinary Biochemistry and Immunology, College of Veterinary Medicine, Chungbuk National University, Cheongju, Chungbuk 361-763, Republic of Korea
\end{abstract}

Received December 14, 2011; Accepted January 20, 2012

DOI: $10.3892 /$ ijmm.2012.903

\begin{abstract}
Various endocrine disrupting chemicals (EDCs) are exogenous compounds found in the environment and have the potential to interfere with the endocrine system and hormonal regulation. Among EDCs, bisphenol A (BPA) and 1,1,1-trichloro-2,2-bis(4-methoxyphenol)-ethane [methoxychlor $(\mathrm{MXC})$ ] have estrogenic activity resulting in a variety of dysfunctions in the E2-mediated response by binding to estrogen receptors (ERs), causing human health problems such as abnormal reproduction and carcinogenesis. In this study, we investigated the effects of BPA and MXC on cell proliferation facilitated by ER signaling in human breast cancer cells. MCF-7 cells are known to be ER $\alpha$-positive and to be a highly E2-responsive cancer cell line; these cells are, therefore, a useful in vitro model for detecting estrogenic activity in response to EDCs. We evaluated cancer cell proliferation following BPA and MXC treatment using an MTT assay. We analyzed alterations in the expression of genes associated with the cell cycle in MCF-7 cells by semi-quantitative reverse-transcription PCR following treatment with BPA or MXC compared to EtOH. To determine whether BPA and MXC stimulate cancer cell growth though ER signaling, we co-treated the cells with agonists (propyl pyrazoletriol, PPT; and diarylpropionitrile, DPN) or an antagonist (ICI 182,780) of ER signaling and reduced ER $\alpha$ gene expression via siRNA in MCF-7 cells before treatment with EDCs. These studies
\end{abstract}

Correspondence to: Dr Kyung-Chul Choi, Laboratory of Veterinary Biochemistry and Immunology, College of Veterinary Medicine, Chungbuk National University, Cheongju, Chungbuk 361-763, Republic of Korea

E-mail: kchoi@cbu.ac.kr

Key words: bisphenol A, methoxychlor, breast cancer, estrogen receptor, cyclin D1,p21 confirmed the carcinogenicity of EDCs in vitro. As a result, BPA and MXC induced the cancer cell proliferation by the upregulation of genes that promote the cell cycle and the downregulation of anti-proliferative genes, especially ones affecting the G1/S transition via ER $\alpha$ signaling. These collective results confirm the carcinogenicity of these EDCs in vitro. Further studies are required to determine whether EDCs promote carcinogenesis in vivo.

\section{Introduction}

Various endocrine disrupting chemicals (EDCs) are exogenous compounds found in the environment (1). EDCs have the potential to interfere with the endocrine system and hormonal regulation (2). These adverse effects of EDCs consequently result in human health problems associated with reproduction, development, and the neurologic and immune systems (3). Most natural and synthetic EDCs tend to have estrogenic activities and structures similar to that of estrogen such as $17 \beta$-estradiol (E2); thus, they induce estrogen-mediated responses by binding to estrogen receptors (ERs) (4). ERs are members of the nuclear receptor family and play a key role as transcription factors (TFs) in gene expression (5). Estrogen is known to be essential for the development of reproductive organs, bone, and the cardiovascular system (6,7). However, many previous studies have shown that estrogen is an important factor in the growth of ER $\alpha$-positive human breast cancer and other cancers (8). Although most EDCs bind to the ER $\alpha$ with an affinity lower than that of E2, these chemicals cause abnormal estrogenic responses in specific tissues as agonists or antagonists of ER signaling $(3,9)$. Abnormal activation of estrogen signaling by EDCs leads to altered gene expression in target tissue and carcinogenesis (10).

Among EDCs, bisphenol A(BPA) and alkylphenols, such as 4-n-nonylphenol (NP) and 4-n-octylphenol (OP), have strong estrogenic activity that results in a variety of dysfunctions in the E2-mediated response (11). BPA is primarily used as a plasticizer and a polystyrene resin for industrial products all over the world. As the use of plastics increases, human exposure to 
BPA has greatly increased (12). Humans have prolonged daily exposure to BPA in plastic materials, such as cans for food products with epoxy resin lining, eyeglass lenses, and dental sealants (13). Many studies have demonstrated that BPA is a potent endocrine disruptor both in vivo and in vitro $(14,15)$. $\mathrm{BPA}$, an EDC known to induce E2-mediated responses via translocation into the nucleus after formation of the ER $\alpha$-bound complex, binds to the estrogen response element (ERE) to promote gene expression. The binding affinity of BPA to the $\mathrm{ER} \alpha$ is approximately 10,000-fold lower than that of E2 (16). Because BPA exhibits ER $\alpha$ agonistic activity and activates constructs containing the ERE promoter, this chemical affects the reproductive system and ER-dependent cancer growth (17). For example, BPA causes phenotypic vaginal alterations and abnormal development of sexual characteristics (18). In addition, BPA increases proliferation of breast cancer cells and progesterone receptor expression in human endometrial cancer cells; this activity can be blocked by ICI 182,780, an antagonist of both $\operatorname{ER} \alpha$ and $\operatorname{ER} \beta$ (19).

Methoxychlor (MXC) is a synthetic chemical used as an alternative pesticide for DDT against a wide variety of insects such as mosquitoes and flies for agriculture and home gardening purposes. MXC has a weak estrogenic activity and can bind to both ERs, resulting in detrimental effects on developmental and reproductive systems (20). For instance, exposure to MXC results in reduced fertility and ovulation with alterations in specific gene expression, and folliculogenesis in the ovary (21). Studies have shown that MXC disturbs spermatogenesis and reduces the size of the testes, prostate, and seminal vesicles in males (22). In addition, MXC exerts a significant proliferative effect on human ovarian cancer cells in a dose-dependent manner (23). However, there are not sufficient data to fully identify the mechanism of MXC action.

Based on this information, we performed the present study to evaluate the effects of BPA and MXC on cancer cell proliferation through ER signaling in human breast cancer cells. MCF-7 cells are known to be ER $\alpha$-positive and to be highly responsive to $\mathrm{E} 2$; these characteristics make the $\mathrm{MCF}-7$ cells a useful in vitro model for detecting the estrogenic effects of EDCs. We examined cancer cell proliferation following EDC treatment using an MTT assay. To determine whether EDCs affect cancer cell growth though ER signaling, we also co-treated the MCF-7 cells with agonists (propyl pyrazoletriol, PPT, and diarylpropionitrile, DPN) or an antagonist (ICI 182,780) of ERs signaling, and reduced ER $\alpha$ gene expression via small inhibitory RNA (siRNA) before EDC treatment. Using semi-quantitative reverse-transcription PCR (RT-PCR), we analyzed the altered expression of genes associated with the cell cycle following treatment with BPA or MXC compared to $\mathrm{EtOH}$ in $\mathrm{MCF}-7$ cells.

\section{Materials and methods}

Cell culture and media. Human breast cancer MCF-7 cells were obtained from the Korean Cell Line Bank (KCLB, Seoul, Republic of Korea). The cells were cultured in Dulbecco's modified Eagle's medium (DMEM; Hyclone Laboratories, Inc., Logan, UT, USA) supplemented with $10 \%$ heat-inactivated fetal bovine serum (FBS; Hyclone Laboratories), $100 \mathrm{IU} / \mathrm{ml}$ penicillin, and $100 \mathrm{mg} / \mathrm{ml}$ streptomycin (Cellgro, Manassas,
VA, USA) at $37^{\circ} \mathrm{C}$ in a humidified $5 \% \mathrm{CO}_{2}$ atmosphere. To eliminate the effects of the estrogenic components in the DMEM and FBS, phenol red-free DMEM supplemented with $10 \%$ charcoal-dextran-treated FBS was used for 3 days. The media were then changed to phenol red-free DMEM supplemented with $1 \%$ charcoal-dextran-treated FBS for 1 days to measure the estrogenic activity of EDCs in the MCF-7 cells.

Cell proliferation assay. The effect of the EDCs on cell proliferation was measured by an MTT assay. MCF-7 cells were plated at a density of 4,000 cells/well in 96-well plates in $0.1 \mathrm{ml}$ of phenol red-free DMEM supplemented with $1 \%$ charcoal-dextran-treated FBS. After incubating for $48 \mathrm{~h}$, the cells were washed and treated with E2, BPA or MXC (all were from Sigma-Aldrich Corp., St. Louis, MO, USA) at various concentrations in the medium described above for 6 days. Ethanol (EtOH; 0.1\%) in the same medium was used as a vehicle. To examine the mechanism of EDCs action, cells were co-treated with $10^{-8} \mathrm{M}$ ICI $182,780,10^{-8} \mathrm{M}$ PPT or $10^{-8} \mathrm{M}$ DPN after exposure the MCF-7 cells to the EDCs. Following these treatments, the cells were treated with $10 \mu \mathrm{l}$ of MTT solution $(5 \mathrm{mg} / \mathrm{ml})$ and incubated at $37^{\circ} \mathrm{C}$ for $4 \mathrm{~h}$. Medium containing the MTT was removed and precipitants were solubilized in EtOH. Absorbance was measured at $540 \mathrm{~nm}$ using an ELISA reader (VERSA man; Molecular Devices, Sunnyvale, CA, USA).

Total-RNA extraction. MCF-7 cells were cultured at a density of $3 \times 10^{5}$ cells/well in 6 -well plates and then were treated with E2, BPA, MXC or EtOH. MCF-7 cells were cultured at a density of $3 \times 10^{5}$ cells/well in 6-well plates, treated with E2, BPA, MXC and EtOH; and co-treated with ICI 182,780, PPT or DPN. Total-RNA was extracted at various time points ( 0,6 and $24 \mathrm{~h})$ using TRIzol reagent (Invitrogen Life Technologies, Carlsbad, CA, USA) according to the manufacturer's instructions. The concentration of total-RNA was measured by a spectrophotometer (Optizen, Mecasys, Dea-jeon, Republic of Korea) at $260 / 280 \mathrm{~nm}$. One microgram of total-RNA was dissolved in diethyl pyrocarbonate-deionzed water (DEPC-DW) for cDNA synthesis.

Semi-quantitative $R T-P C R$. To synthesize cDNA from totalRNA using RT-PCR, the reaction mixture contained murine leukemia virus reverse transcriptase (M-MLV RT), nonamer random primers, dNTPs, an RNase inhibitor, and RT buffer (all were from Intron Biotechnology, Sungnam, Kyeonggido, Republic of Korea). cDNA synthesis was performed at $37^{\circ} \mathrm{C}$ for $1 \mathrm{~h}$ and $95^{\circ} \mathrm{C}$ for $5 \mathrm{~min}$. Cyclin D,p21, ER $\alpha$ and GAPDH mRNA were amplified with specific forward and reverse primers, Taq polymerase, PCR buffer, dNTP mixture, and each cDNA template; PCR was performed as previously described (24). The sequences for each forward and reverse primer and the expected sizes of the PCR products are shown in Table I. The PCR products were separated on a $1.5 \%$ agarose gel and the band sizes were estimated according to 100-bp ladders. The gels were scanned and band densities were quantified using Gel Doc 2000 (Bio-Rad Laboratories, Inc., Hercules, CA, USA).

Treatment with siRNA. siRNA specific for $\mathrm{ER} \alpha$ (Invitrogen) was designed using BLOCK-iT ${ }^{\mathrm{TM}}$ RNAi Designer (Invitrogen). 
Table I. Primer sequences and predicted sizes of the semi-quantitative reverse-transcription PCR products.

\begin{tabular}{lll}
\hline Target gene & & \multicolumn{1}{c}{ Primer sequences } \\
\hline Cyclin D1 & Sense: & 5'-TCTAAGATGAAGGAGACCATC-3' \\
& Antisense: & 5'-GCGGTAGTAGGACAGGAAGTTGTT-3' \\
p21 & Sense: & 5'-AGGCACCGAGGCACTCAGAG-3' \\
& Antisense: & 5'-TGACAGGTCCACATGGTCTTCC-3' \\
ER & Sense: & 5'-AGACATGAGAGCTGCCAACC-3' bp \\
& Antisense: & 5'-GCCAGGCACATTCTAGAAGG-3' \\
GAPDH & Sense: & 5'-ATGTTCGTCATGGGTGTGAACCA-3' \\
& Antisense: & 5'-TGGCAGGTTTTCTAGACGGCAG-3' \\
\end{tabular}

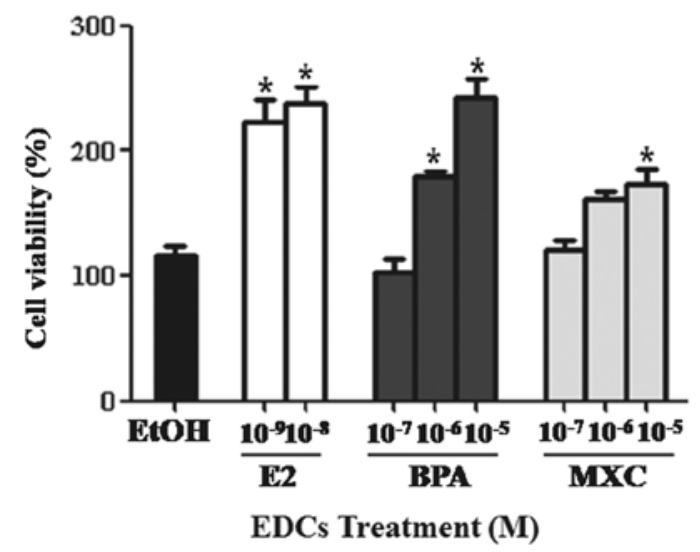

Figure 1. Increased proliferation of MCF-7 cells following treatment with E2, BPA or MXC. MCF-7 cells were treated with EtOH as a vehicle, E2 $\left(10^{-9}\right.$ and $\left.10^{-8} \mathrm{M}\right)$, BPA $\left(10^{-7}-10^{-5} \mathrm{M}\right)$, or MXC $\left(10^{-7}-10^{-5} \mathrm{M}\right)$ for 6 days. The proliferation of cells following EDC treatment was measured using an MTT assay. Data are the mean \pm SD of triplicate experiments. ${ }^{*} \mathrm{P}<0.05$ compared to vehicletreated cells.

knockdown of ER $\alpha$ was achieved by transfecting siRNA into MCF-7 cells using Lipofectamine ${ }^{\mathrm{TM}} 2000$ (Invitrogen). Prior to transfection, the medium was replaced with DMEM without antibiotics. Lipofectamine 2000-siRNA complexes were incubated for $20 \mathrm{~min}$ at room temperature and then added to the cells. The cells were then incubated in an incubator at $37^{\circ} \mathrm{C}$ for $24 \mathrm{~h}$.

Data analysis. Data are shown as the mean \pm standard deviation (SD). A statistical analysis was performed using Student's t-test and two-pair comparisons. P-values $<0.05$ was considered statistically significant.

\section{Results}

Effects of BPA and MXC on cell proliferation in MCF-7 cells. To evaluate the effects of BPA and MXC on cell proliferation, MCF-7 cells were cultured with vehicle $(0.1 \% \mathrm{EtOH})$, E2 $\left(10^{-9}\right.$ and $\left.10^{-8} \mathrm{M}\right)$, BPA $\left(10^{-7}-10^{-5} \mathrm{M}\right)$, or $\mathrm{MXC}\left(10^{-7}-10^{-5} \mathrm{M}\right)$ for 6 days. $\mathrm{E} 2$ as a positive control markedly increased $\mathrm{MCF}-7$ cell proliferation compared to EtOH (Fig. 1). BPA significantly increased MCF-7 cell proliferation in a dose-dependent manner. MXC also stimulated the growth of MCF-7 cells up to a concentration of $10^{-5} \mathrm{M}$ (Fig. 1). These findings showed that BPA and MXC strongly induce the proliferation of MCF-7 cells.

Alteration of cyclin $D 1$ and p21 gene expression by $B P A$ and $M X C$. To evaluate the effects on the expression of genes associated with cell the cycle such as cyclin D1 and $p 21$, we treated the cells with increasing concentrations of BPA $\left(10^{-6} \mathrm{M}\right)$ or MXC $\left(10^{-6} \mathrm{M}\right)$ for 0 to $24 \mathrm{~h}$, based on results of the cell proliferation assay. Semi-quantitative RT-PCR showed that the expression of cyclin D1 was significantly increased by treatment with E2 or BPA compared to EtOH at each time point, but was unaffected by MXC (Fig. 2A). However, p21 expression was significantly decreased in MCF-7 cells treated with both EDCs (Fig. 2B). These results suggested that BPA and MXC can alter the expression of cell cycle-related genes in breast cancer cells; these include the upregulation of cyclin DI and downregulation of $p 21$.

Effects of BPA and MXC on proliferation of MCF-7 cells with an ER antagonist or ER agonists. We incubated MCF-7 cells with an ER antagonist, ICI 182,780, or agonists, PPT and DPN, and co-treated with BPA or MXC. ICI 182,780 significantly decreased the proliferation induced by E2, BPA or MXC in MCF-7 cells (Fig. 3A). This result demonstrated that BPA and MXC can promote proliferation of MCF-7 cells through ER signaling. However, the ER $\alpha$ agonist PPT increased cell proliferation induced by BPA and significantly increased that of MXC (Fig. 3B). However, the ER $\beta$ agonist, did not increase the effects of DPN, E2, BPA or MXC on proliferation (Fig. 3C). These results suggest that increased MCF-7 cell proliferation by BPA or MXC is more closely associated with $\mathrm{ER} \alpha$ than $\mathrm{ER} \beta$.

Effects of BPA and MXC on altered expression of cyclin DI and p21 with an ER antagonist or ER agonists. Functionally blocking $\mathrm{ER} \alpha$ and $\mathrm{ER} \beta$ signaling in cells co-treated with ICI 182,780 and E2, BPA and MXC did not produce significant changes in cyclin D1 and $p 21$ expression levels compared with EtOH treatment (Figs. 4A and 5A). The expression pattern of the cyclin D1 (Fig. 4B and C) and $p 21$ (Fig. 5B and C) genes induced by BPA and $\mathrm{MXC}$ in the presence of the agonists 
A

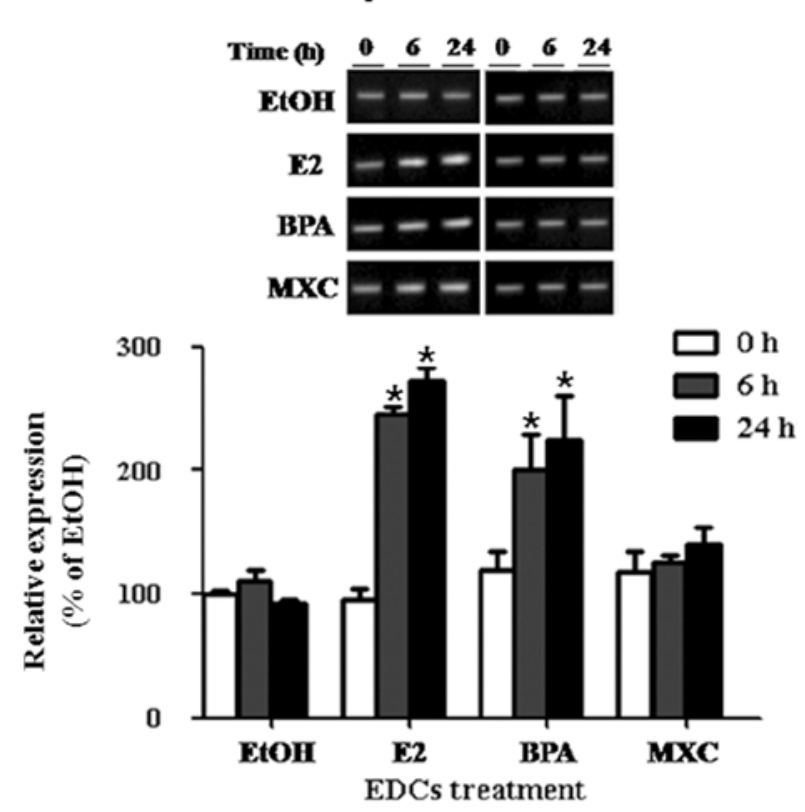

B

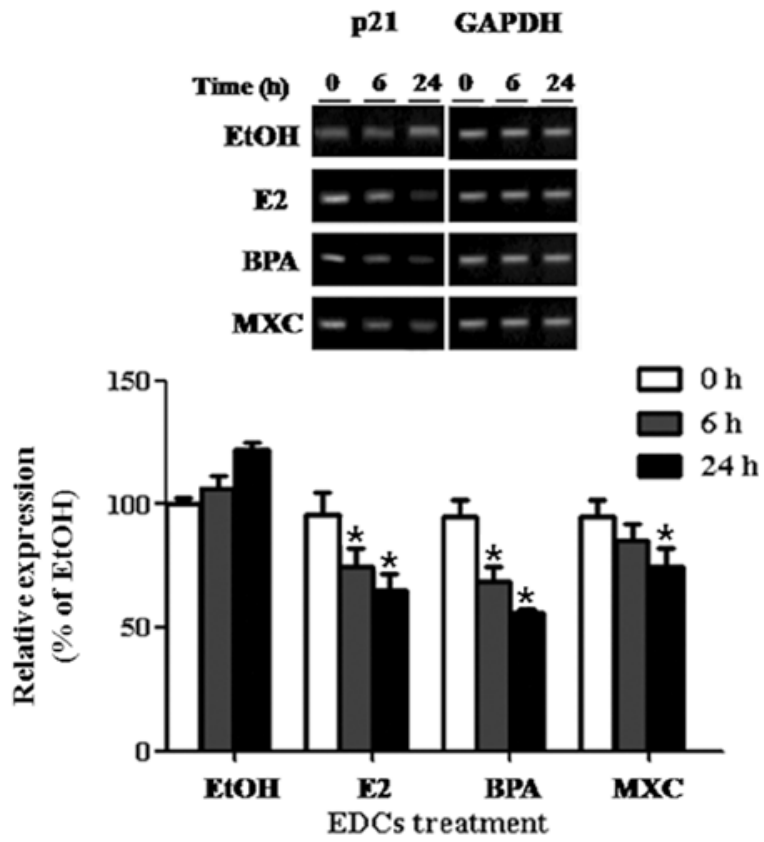

Figure 2. Altered expression of cyclin D1 and $p 21$ genes following treatment with E2, BPA or MXC. MCF-7 cells were seeded in 6-well plates and treated with E2 $\left(10^{-8} \mathrm{M}\right)$, BPA $\left(10^{-6} \mathrm{M}\right)$ or MXC $\left(10^{-6} \mathrm{M}\right)$. Total-RNA was extracted at different time points $(0,6$ and $24 \mathrm{~h})$. Gene expression of (A) cyclin D1 and (B) $p 21$ was detected using semi-quantitative RT-PCR. The PCR products were separated on a $1.5 \%$ agarose gel, the resulting bands were scanned, and the density of the bands in the gel was quantified using Gel Doc 2000 as described in Materials and methods. Data represent the mean \pm SD of triplicate experiments. ${ }^{*} \mathrm{P}<0.05$ compared to vehicle-treated $(\mathrm{EtOH})$ cells.

PPT and DPN were similar to that of cyclin D1 and $p 21$ genes induced by BPA or MXC alone. These results imply that the estrogenic activity of BPA and MXC on cyclin DI and $p 21$ gene expression may result in part from binding to ERs and signaling through the ERs. Effects of BPA and MXC appear to
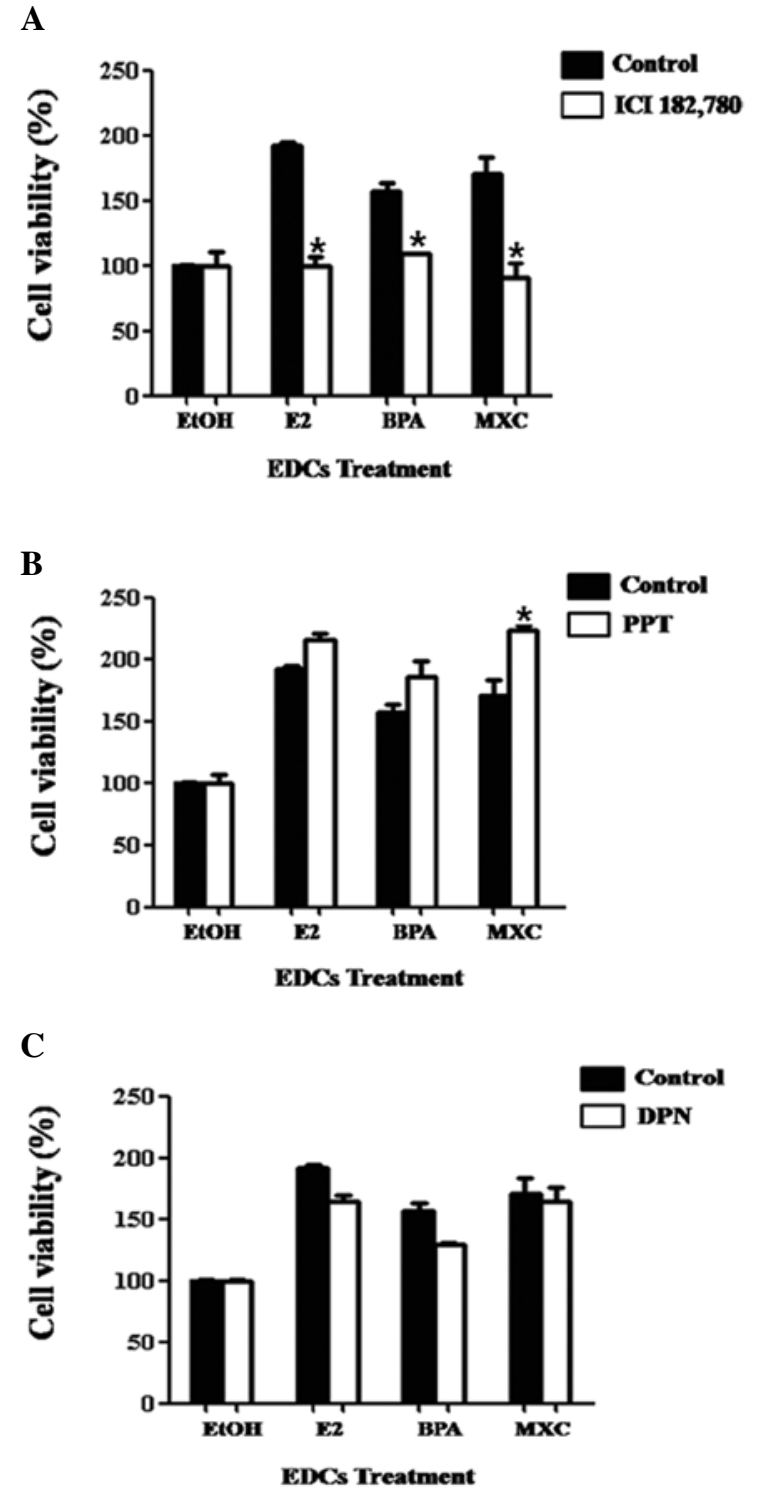

Figure 3. Effects of the ER antagonist or agonist on cell proliferation promoted by E2, BPA or MXC. MCF-7 cells were treated with EtOH as a vehicle, E2 $\left(10^{-9} \mathrm{M}\right)$, BPA $\left(10^{-6} \mathrm{M}\right)$ or MXC $\left(10^{-6} \mathrm{M}\right)$ in the presence or absence of (A) the ER antagonist ICI 182,780 $\left(10^{-8} \mathrm{M}\right)$. (B) The ER $\alpha$ agonist PPT $\left(10^{-8} \mathrm{M}\right)$, or $(\mathrm{C})$ the ER $\beta$ agonist DPN $\left(10^{-8} \mathrm{M}\right)$ for 6 days. Proliferation of the MCF-7 cells were measured using an MTT assay. Data represent the mean \pm SD of triplicate experiments. " $\mathrm{P}<0.05$ compared to vehicle-treated cells.

be involved in the transcriptional regulation of cyclin $D 1$ and p21 through ER signaling.

Effects of E2, BPA or MXC on cyclin D1 and p21 expression in MCF-7 cells transfected with siRNA specific for ERa. The effects of BPA and MXC were evaluated in MCF-7 cells in which ER $\alpha$ expression was reduced by siRNA knockdown. Reduced expression of ER $\alpha$ in siRNA-transfected MCF-7 cells was confirmed by semi-quantitative RT-PCR (Fig. 6A). Expression of the cell cycle-associated genes cyclin D1 and p21 was not altered by E2, BPA or MXC treatment compared to EtOH (Fig. 6B and C). These results indicate that ER $\alpha$ may be involved in altered expression of cell cycle-related genes associated with EDCs. 
A
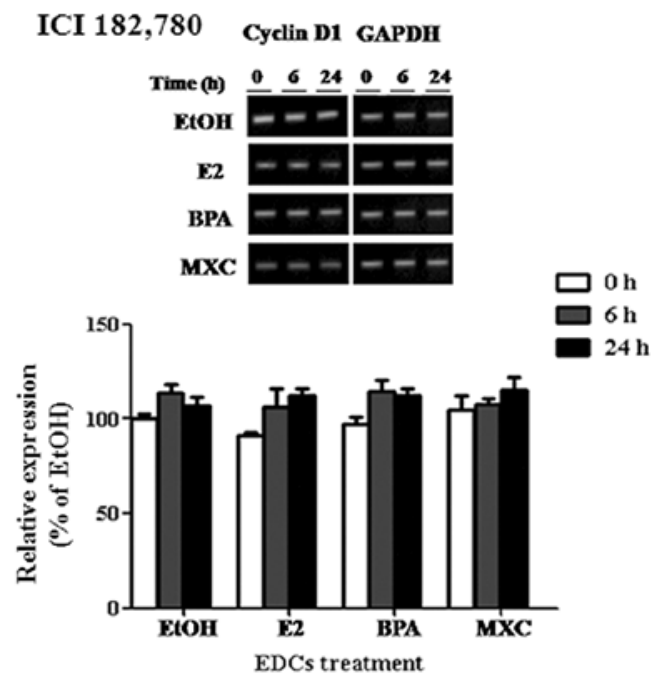

B

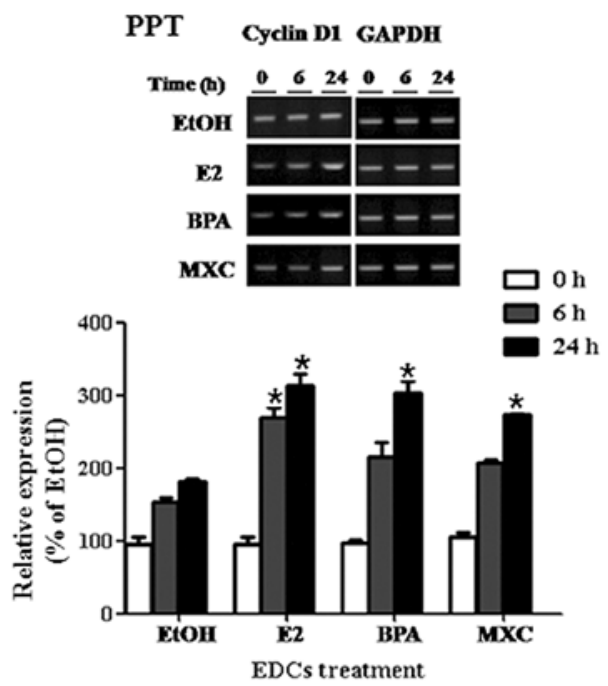

C
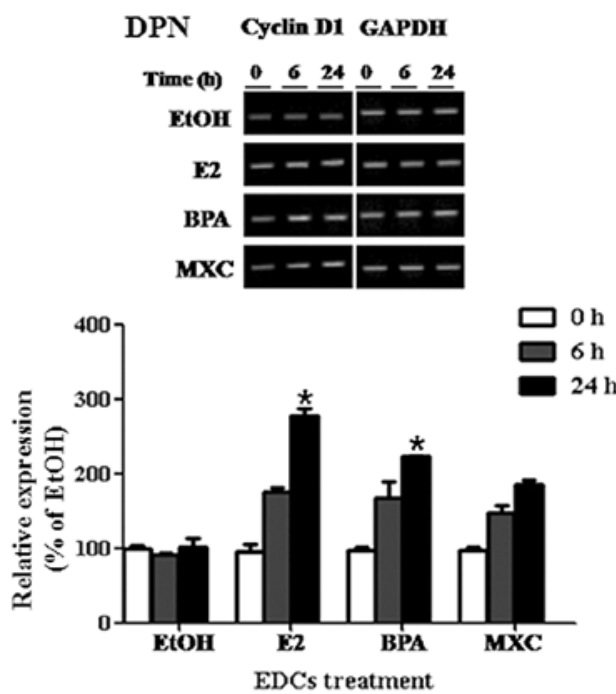

Figure 4. Effects of an ER antagonist or ER agonists on the expression of cyclin D1 altered by E2, BPA or MXC. MCF-7 cells were seeded in 6-well plates and treated with E2 $\left(10^{-8} \mathrm{M}\right)$, BPA $\left(10^{-6} \mathrm{M}\right)$ or MXC $\left(10^{-6} \mathrm{M}\right)$ in the presence or absence of (A) the ER antagonist ICI 182,780 $\left(10^{-8} \mathrm{M}\right)$, (B) the ER $\alpha$ agonist PPT $\left(10^{-8} \mathrm{M}\right)$ or $(\mathrm{C})$ the ER $\beta$ agonist DPN $\left(10^{-8} \mathrm{M}\right)$. Total-RNA was extracted at different time points ( 0,6 and $24 \mathrm{~h})$. Expression levels of cyclin D1 were measured using semi-quantitative RT-PCR as described in Materials and methods. Data represent the mean \pm SD of triplicate experiments. ${ }^{*} \mathrm{P}<0.05$ compared to vehicle-treated $(\mathrm{EtOH})$ cells.
A
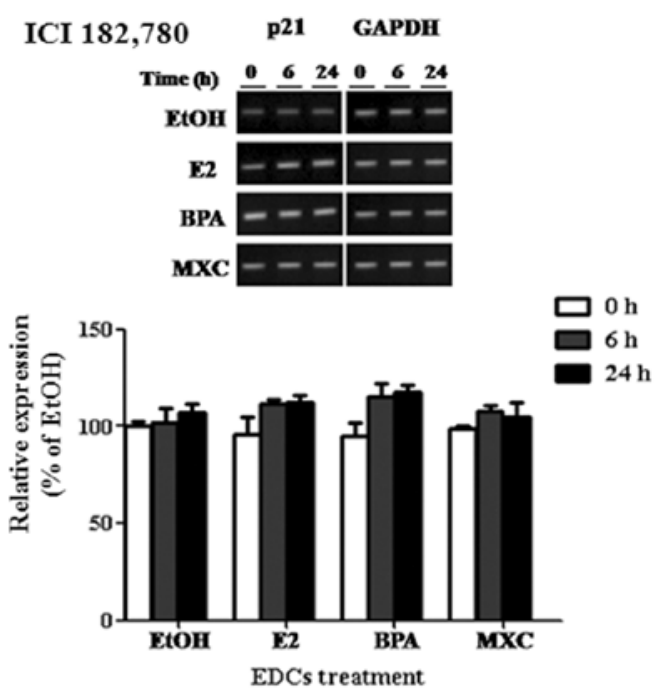

B
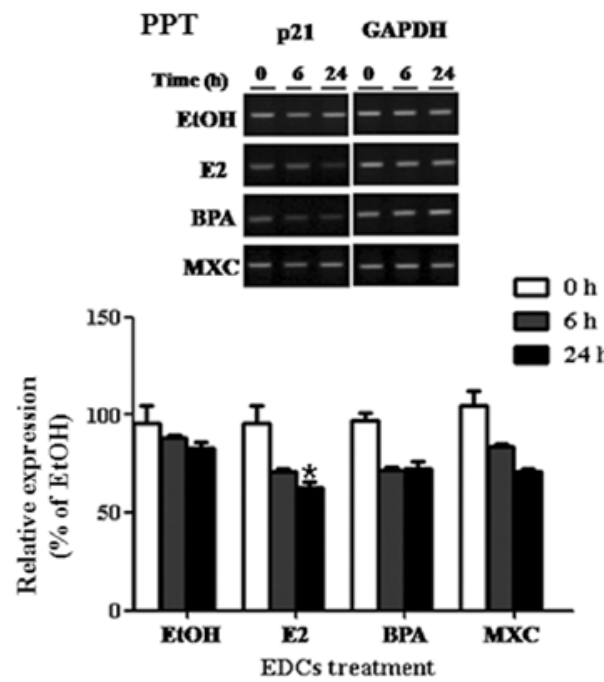

C
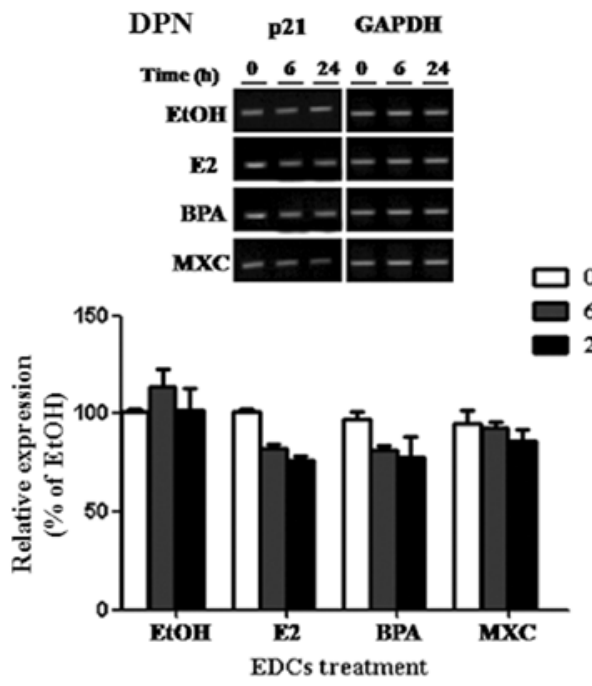

Figure 5. Effects of an ER antagonist or ER agonists on the expression of $p 21$ increased by E2, BPA or MXC. MCF-7 cells were seeded in 6-well plates and treated with E2 $\left(10^{-8} \mathrm{M}\right)$, BPA $\left(10^{-6} \mathrm{M}\right)$ or MXC $\left(10^{-6} \mathrm{M}\right)$ in the presence or absence of (A) the ER antagonist ICI $182,780\left(10^{-8} \mathrm{M}\right)$, (B) the ERo agonist PPT $\left(10^{-8} \mathrm{M}\right)$, or $(\mathrm{C})$ the ER $\beta$ agonist DPN $\left(10^{-8} \mathrm{M}\right)$. Total-RNA was extracted at different time points $(0,6$ and $24 \mathrm{~h})$. Expression levels of $p 21$ were measured using semi-quantitative RT-PCR as described in Materials and methods. Data represent the mean \pm SD of triplicate experiments. ${ }^{*} \mathrm{P}<0.05$ compared to vehicle-treated $(\mathrm{EtOH})$ cells. 
A

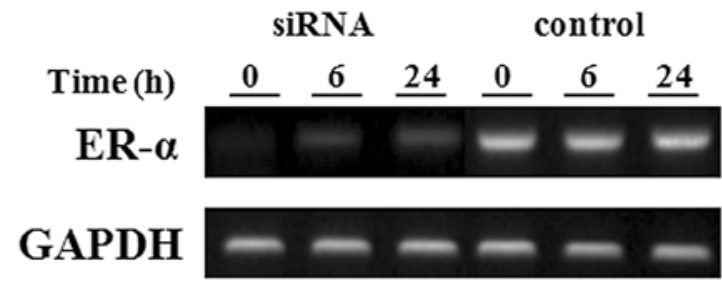

B

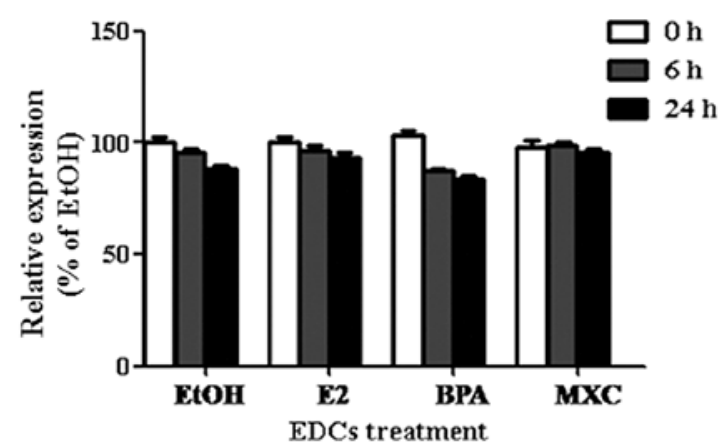

C
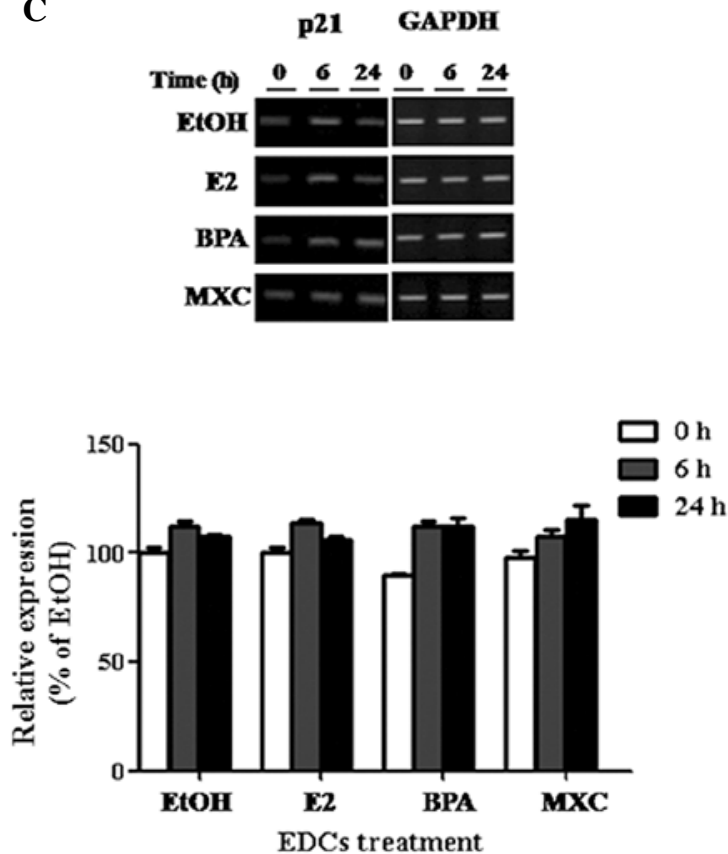

Figure 6. Effects of E2, BPA or MXC on the expression of cyclin D1 and p21 in MCF-7 cells transfected with siRNA specific for ER $\alpha$. (A) MCF-7 cells were transfected with small inhibitory RNA (siRNA) specific for ER $\alpha$. Expression of ER $\alpha$ was then measured using semi-quantitative RT-PCR. (B) MCF-7 cells transfected with ER $\alpha$-specific siRNA were treated with E2 $\left(10^{-8} \mathrm{M}\right)$, BPA $\left(10^{-6} \mathrm{M}\right)$ or MXC $\left(10^{-6} \mathrm{M}\right)$. The expression levels of $c y c l i n$ D1 and $p 21$ genes were measured using semi-quantitative RT-PCR as described in Materials and methods. Data represent the mean \pm SD of triplicate experiments. ${ }^{*} \mathrm{P}<0.05$ compared to vehicle-treated $(\mathrm{EtOH})$ cells.

\section{Discussion}

Estrogen stimulates the proliferation of breast cancer cells via binding to ERs. Some studies have shown that E2 induces the transition from the $\mathrm{G} 1$ to the $\mathrm{S}$ phase of the cell cycle and robust proliferation in MCF-7 cells as well as other ER-positive breast cancer cells (25). The G1/S transition during the cell cycle involves many important cell cycle-related genes such as cyclin D1,p21, and $c d k 4$; the expression of these genes may be specifically altered in breast cancer cells (26). Cyclin D1 is overexpressed in nearly $50 \%$ of breast cancers and a well-defined target of E2-mediated signaling in ER-positive cancer cells such as MCF-7 (27). In MCF-7 cells, treatment of G0/G1-arrested cells with E2 significantly upregulates cyclin D1 mRNA and protein expression (28). In addition, E2 modulates the function of cell cycle regulators such as p21, p27 and p16 (29). As a negative regulator of cell cycle progression, p21 is a potential cancer suppressor gene. Recently, some studies have shown that p21 plays an essential role in inhibiting breast cancer growth during the G1/S transition (30). However, estrogen can regulate p21 expression in ER-positive breast cancer cells (31). The data suggest that these EDCs can induce E2-mediated alterations in cancer due to their estrogenic effect on ER-positive cells.

Among the EDCs, BPA has attracted considerable attention. BPA can act in a manner similar to E2 in the body (32) and has estrogenic activity that stimulates the proliferation of ER-positive mammary cancer cells (33). In addition, there are in vitro and in vivo data which demonstrates that BPA promotes prostate cancer growth in cells harboring an androgen receptor mutation (34). Recent studies have demonstrated that the estrogenic activity of MXC provides evidence for EDC action in many tissues including the uterus, vagina, brain and bone (35). MXC can bind to ER $\alpha$ and ER $\beta$, which suggest that MXC may be associated with E2-mediated responses in humans (36).

In the present study, we confirmed that BPA or MXC stimulate carcinogenesis and induce a change at the transcriptional level of the expression of cell-related genes in ER-positive human breast cancer cells. They increased the proliferation of MCF-7 cells in a dose-dependent manner, similarly to E2. We also found that they cause the induction of cyclin D1 expression and reduced $p 21$ expression associated with the G1/S 
transition, resulting in the proliferation of MCF-7 cells. The data suggest that increased progression of G1/S transition due to exposure to EDCs may result in a poor prognosis for human breast cancer patients.

However, increased proliferation and altered expression of cell cycle-related genes due to BPA and MXC in MCF-7 cells were inhibited by the ER antagonist ICI 182,780. This result suggests that the effects of BPA and MXC on cancer cells occurs through ER signaling. In addition, we determined that the effects of BPA and MXC on MCF-7 cells are exerted mainly through ER $\alpha$ rather than ER $\beta$ signaling. PPT is a potent $\mathrm{ER} \alpha$ agonist that has a binding affinity for $\mathrm{ER} \alpha$ up to 400 -fold higher than for ER $\beta$ (37). Furthermore, DPN as an $\mathrm{ER} \beta$ agonist is 70 -fold more selective for $\mathrm{ER} \beta$ than $\mathrm{ER} \alpha$ (38). The effects of BPA and MXC were enhanced in the presence of PPT. The expression of cyclin D1 and $p 21$ were potentiated by BPA or MXC in the presence of PPT, but were less altered by BPA or MXC with DPN. These results show that activation of ER $\alpha$ signaling by PPT can promote the effect of BPA or MXC at the transcriptional level of cell cycle-regulating genes.

To confirm the relationship between ER $\alpha$ and EDCs, we transfected siRNA of ER $\alpha$ into MCF-7 cells. As the expression of ER $\alpha$ was reduced in MCF-7 cells, the effects of BPA and MXC disappeared on both the expression of cyclin D1 and $p 21$. These studies indicate that EDCs can stimulate the proliferation of human breast cancer cells through ER $\alpha$. Activation of ER $\alpha$ signaling by EDCs leads to altered regulation of cyclin D1 and $p 21$ gene expression that results in significant proliferation of cancer cells.

Taken together, our findings allow us to postulate that BPA and $\mathrm{MXC}$ may have carcinogenic properties in vitro. BPA and MXC induce upregulated expression of cell cycle-associated genes and downregulate the expression of anti-proliferative genes, especially ones that influence the G1/S transition via $\mathrm{ER} \alpha$ signaling. This collectively results in the formation of mammary cancer cells and sustained proliferation. Further studies are required to determine whether EDCs promote carcinogenesis in vivo.

\section{Acknowledgements}

This study was supported by a National Research Foundation of Korea (NRF) grant (no. 2011-0015385) funded by the Republic of Korea Government (MEST).

\section{References}

1. Nikaido Y, Danbara N, Tsujita-Kyutoku M, Yuri T, Uehara N and Tsubura A: Effects of prepubertal exposure to xenoestrogen on development of estrogen target organs in female CD-1 mice. In Vivo 19: 487-494, 2005.

2. Migliarini B, Piccinetti CC, Martella A, Maradonna F, Gioacchini $G$ and Carnevali O: Perspectives on endocrine disruptor effects on metabolic sensors. Gen Comp Endocrinol 170: 416-423, 2011

3. Choi KC and Jeung EB: The biomarker and endocrine disruptors in mammals. J Reprod Dev 49: 337-345, 2003.

4. Dang VH, Nguyen TH, Lee GS, Choi KC and Jeung EB: In vitro exposure to xenoestrogens induces growth hormone transcription and release via estrogen receptor-dependent pathways in rat pituitary GH3 cells. Steroids 74: 707-714, 2009.

5. Bondar G, Kuo J, Hamid N and Micevych P: Estradiol-induced estrogen receptor-alpha trafficking. J Neurosci 29: 15323-15330, 2009 .
6. Pacifici R: Estrogen deficiency, T cells and bone loss. Cell Immunol 252: 68-80, 2008.

7. Li J and McMurray RW: Effects of estrogen receptor subtypeselective agonists on immune functions in ovariectomized mice. Int Immunopharmacol 6: 1413-1423, 2006.

8. Varshochi R, Halim F, Sunters A, Alao JP, Madureira PA, Hart SM, Ali S, Vigushin DM, Coombes RC and Lam EW: ICI182,780 induces p21Waf1 gene transcription through releasing histone deacetylase 1 and estrogen receptor alpha from Sp1 sites to induce cell cycle arrest in MCF-7 breast cancer cell line. J Biol Chem 280: 3185-3196, 2005.

9. Vandenberg LN, Hauser R, Marcus M, Olea N and Welshons WV: Human exposure to bisphenol A (BPA). Reprod Toxicol 24: 139-177, 2007.

10. Choi SM, Yoo SD and Lee BM: Toxicological characteristics of endocrine-disrupting chemicals: developmental toxicity, carcinogenicity, and mutagenicity. J Toxicol Environ Health B Crit Rev 7: 1-24, 2004

11. Bonefeld-Jorgensen EC, Long M, Hofmeister MV and Vinggaard AM: Endocrine-disrupting potential of bisphenol A. bisphenol A dimethacrylate, 4-n-nonylphenol, and 4-n-octylphenol in vitro: new data and a brief review. Environ Health Perspect 115 (Suppl 1): 69-76, 2007.

12. Mielke H and Gundert-Remy U: Bisphenol A levels in blood depend on age and exposure. Toxicol Lett 190: 32-40, 2009.

13. Braun JM, Yolton K, Dietrich KN, Hornung R, Ye X, Calafat AM and Lanphear BP: Prenatal bisphenol A exposure and early childhood behavior. Environ Health Perspect 117: 1945-1952, 2009.

14. Wadia PR, Vandenberg LN, Schaeberle CM, Rubin BS, Sonnenschein $\mathrm{C}$ and Soto AM: Perinatal bisphenol A exposure increases estrogen sensitivity of the mammary gland in diverse mouse strains. Environ Health Perspect 115: 592-598, 2007.

15. Izzotti A, Kanitz S, D'Agostini F, Camoirano A and De Flora S: Formation of adducts by bisphenol A, an endocrine disruptor, in DNA in vitro and in liver and mammary tissue of mice. Mutat Res 679: 28-32, 2009.

16. Dang VH, Choi KC, Hyun SH and Jeung EB: Analysis of gene expression profiles in the offspring of rats following maternal exposure to xenoestrogens. Reprod Toxicol 23: 42-54, 2007.

17. Tillett T: Bisphenol A, chapter 2: new data shed light on exposure, potential bioaccumulation. Environ Health Perspect 117: A210, 2009.

18. Hunt PA, Susiarjo M, Rubio C and Hassold TJ: The bisphenol A experience: a primer for the analysis of environmental effects on mammalian reproduction. Biol Reprod 81: 807-813, 2009.

19. Keri RA, Ho SM, Hunt PA, Knudsen KE, Soto AM and Prins GS: An evaluation of evidence for the carcinogenic activity of bisphenol A. Reprod Toxicol 24: 240-252, 2007.

20. Suzuki M, Lee HC, Chiba S, Yonezawa T and Nishihara M: Effects of methoxychlor exposure during perinatal period on reproductive function after maturation in rats. J Reprod Dev 50: 455-461, 2004

21. Armenti AE, Zama AM, Passantino L and Uzumcu M: Developmental methoxychlor exposure affects multiple reproductive parameters and ovarian folliculogenesis and gene expression in adult rats. Toxicol Appl Pharmacol 233: 286-296, 2008.

22. Amstislavsky SY, Amstislavskaya TG, Amstislavsky VS, Tibeikina MA, Osipov KV and Eroschenko VP: Reproductive abnormalities in adult male mice following preimplantation exposures to estradiol or pesticide methoxychlor. Reprod Toxicol 21: 154-159, 2006.

23. Park SH, Kim KY, An BS, Choi JH, Jeung EB, Leung PC and Choi KC: Cell growth of ovarian cancer cells is stimulated by xenoestrogens through an estrogen-dependent pathway, but their stimulation of cell growth appears not to be involved in the activation of the mitogen-activated protein kinases ERK-1 and p38. J Reprod Dev 55: 23-29, 2009.

24. Yi BR, Kang NH, Hwang KA, Kim SU, Jeung EB and Choi KC: Antitumor therapeutic effects of cytosine deaminase and interferon-beta against endometrial cancer cells using genetically engineered stem cells in vitro. Anticancer Res 31: 2853-2861, 2011.

25. Felty Q, Singh KP and Roy D: Estrogen-induced G1/S transition of $\mathrm{G0}$-arrested estrogen-dependent breast cancer cells is regulated by mitochondrial oxidant signaling. Oncogene 24: 4883-4893, 2005.

26. Foster JS, Henley DC, Ahamed S and Wimalasena J: Estrogens and cell-cycle regulation in breast cancer. Trends Endocrinol Metab 12: 320-327, 2001. 
27. Yano M, Naito Z, Yokoyama M, Shiraki Y,Ishiwata T, Inokuchi M and Asano G: Expression of hsp90 and cyclin D1 in human breast cancer. Cancer Lett 137: 45-51, 1999.

28. Aaltonen K, Amini RM, Landberg G, Eerola H, Aittomaki K, Heikkila P, Nevanlinna $\mathrm{H}$ and Blomqvist C: Cyclin D1 expression is associated with poor prognostic features in estrogen receptor positive breast cancer. Breast Cancer Res Treat 113: 75-82, 2009

29. Cheng WL, Lin TY, Tseng YH, Chu FH, Chueh PJ, Kuo YH and Wang SY: Inhibitory effect of human breast cancer cell proliferation via p21-mediated G1 cell cycle arrest by araliadiol isolated from Aralia cordata Thunb. Planta Med 77: 164-168, 2011.

30. Wang X, Gao P, Long M, Lin F, Wei JX, Ren JH, Yan L, He T, Han Y and Zhang HZ: Essential role of cell cycle regulatory genes p21 and p27 expression in inhibition of breast cancer cells by arsenic trioxide. Med Oncol 28: 1225-1254, 2011.

31. Mandal S and Davie JR: Estrogen regulated expression of the p21 Waf1/Cip1 gene in estrogen receptor positive human breast cancer cells. J Cell Physiol 224: 28-32, 2010.

32. Hong EJ, Choi KC and Jeung EB: Induction of calbindin-D9k messenger RNA and protein by maternal exposure to alkylphenols during late pregnancy in maternal and neonatal uteri of rats. Biol Reprod 71: 669-675, 2004.

33. Rivas A, Lacroix M, Olea-Serrano F, Laios I, Leclercq G and Olea N: Estrogenic effect of a series of bisphenol analogues on gene and protein expression in MCF-7 breast cancer cells. J Steroid Biochem Mol Biol 82: 45-53, 2002.
34. Ho SM, Tang WY, Belmonte de Frausto $\mathrm{J}$ and Prins GS: Developmental exposure to estradiol and bisphenol A increases susceptibility to prostate carcinogenesis and epigenetically regulates phosphodiesterase type 4 variant 4 . Cancer Res 66: 5624-5632, 2006.

35. Shin JH, Moon HJ, Kang IH, Kim TS, Lee SJ, Oh JY, Lee YJ, Hong EJ, Jeung EB and Han SY: Calbindin-D9k mRNA expression in the rat uterus following exposure to methoxychlor: a comparison of oral and subcutaneous exposure. J Reprod Dev 53: 179-188, 2007.

36. Ottinger MA, Wu JM, Hazelton JL, Abdelnabi MA, Thompson N, Quinn ML Jr, Donoghue D, Schenck F, Ruscio M, Beavers J and Jaber M: Assessing the consequences of the pesticide methoxychlor: neuroendocrine and behavioral measures as indicators of biological impact of an estrogenic environmental chemical. Brain Res Bull 65: 199-209, 2005.

37. Stauffer SR, Coletta CJ, Tedesco R, Nishiguchi G, Carlson K, Sun J, Katzenellenbogen BS and Katzenellenbogen JA: Pyrazole ligands: structure-affinity/activity relationships and estrogen receptor-alpha-selective agonists. J Med Chem 43: 4934-4947, 2000.

38. Meyers MJ, Sun J, Carlson KE, Marriner GA, Katzenellenbogen BS and Katzenellenbogen JA: Estrogen receptor-beta potencyselective ligands: structure-activity relationship studies of diarylpropionitriles and their acetylene and polar analogues. J Med Chem 44: 4230-4251, 2001. 